\title{
Chemical defenses in the sea hare Aplysia parvula: importance of diet and sequestration of algal secondary metabolites
}

\author{
David W. Ginsburg*, Valerie J. Paul ${ }^{* *}$ \\ Marine Laboratory, University of Guam, UOG Station, Mangilao, Guam 96923, USA
}

\begin{abstract}
Marine algae produce a variety of secondary metabolites that function as herbivore deterrents. Algal metabolites, however, often fail to deter damage by some herbivores such as mesograzers that both live and feed on their host alga. In addition, the degree to which intraspecific chemical variation in an alga affects a mesograzer's feeding behavior and its ability to deter predators is poorly understood. The red alga Portieria hornemannii contains the secondary metabolites apakaochtodene A and B, which have been shown to vary in concentration among sites on Guam and act as significant deterrents to fish feeding. On Guam, the sea hare Aplysia parvula preferred and grew best when fed its algal host $P$. hornemannii. However, high concentrations of $P$. hornemannii crude extract and the pure compounds apakaochtodene A and B acted as feeding deterrents to A. parvula. Despite differences among sites in the levels of apakaochtodenes A and B, A. parvula showed no significant preference for $P$. hornemannii from any one location. Aplysia parvula found on $P$. hornemannii sequestered apakaochtodenes, and both whole animals and body parts were unpalatable to reef fishes. Sea hares found on the red alga Acanthophora spicifera, which contains no unpalatable secondary metabolites, had no apakaochtodene compounds and were eaten by fishes. This observation is consistent with the hypothesis that diet-derived algal metabolites in sea hares play a role in deterring predation.
\end{abstract}

KEY WORDS: Sea hare $\cdot$ Tri-trophic interaction - Antipredator chemical defense $\cdot$ Apakaochtodene A and B $\cdot$ Aplysia $\cdot$ Portieria $\cdot$ Guam

Resale or republication not permitted without written consent of the publisher

\section{INTRODUCTION}

Marine algae produce a variety of secondary metabolites that function as herbivore deterrents (Hay \& Fenical 1988, Paul 1992, Hay 1996). Under natural conditions, these compounds provide a selective advantage to the algae (Hay 1992, 1996, Paul 1992). Algal secondary metabolites may also have other roles as defenses against pathogens and fouling organisms, thus increasing the adaptive value of these metabolites (Paul 1992, Schmitt et al. 1995).

\footnotetext{
*Present address: Dept of Biological Sciences, University of Southern California, Los Angeles, California 90089, USA ${ }^{* *}$ Corresponding author. E-mail: vpaul@uog9.uog.edu
}

Algal metabolites fail to deter damage by some herbivores and may stimulate feeding by small, relatively sedentary herbivores such as amphipods, crabs, polychaetes, and some gastropods. These herbivores, collectively termed mesograzers, both live and feed on their algal host (Hay et al. 1989, 1990a,b, Brawley 1992, Hay 1992, Trowbridge 1992, Di Marzo et al. 1993). It has been hypothesized that the preference of some mesograzers for chemically-defended algae has been driven primarily by the advantages of decreased predation that mesograzers might experience while living and feeding on a host plant that is a deterrent to reef fishes (Hay et al. 1987, 1989, 1990a,b, Hay 1992, 1996).

The degree to which intraspecific chemical variation in an alga affects a mesograzer's feeding behavior and 
its ability to deter predators is poorly understood. While several studies have examined quantitative variation in algal secondary chemistry (Carlton et al. 1989, Meyer \& Paul 1992, 1995, de Nys et al. 1996, 1998, Puglisi \& Paul 1997, Matlock et al. 1999), few have examined the effects of within-algal variation on the feeding preferences of mesograzers (Van Alstyne 1989, Poore 1994, Cronin \& Hay 1996a,b). Such studies are necessary not only to understand the factors affecting the production of chemical defenses, but also to provide insight into the ecological consequences of such variation (Hay 1996, Becerro et al. 1998).

How intraspecific variation of algal secondary metabolites influences the vulnerability of mesograzers to predation has not been examined. These types of interactions can best be studied by examining the chemistry as well as the palatability of organisms within an alga-mesograzer-predator, or tri-trophic, system. In this study, we chose to investigate the red alga Portieria hornemannii (Lyngbye) Silva (Gigartinales: Rhizophyllidaceae), the mesograzer Aplysia parvula Mörch (Opisthobranchia: Anaspidea) and generalist, reef fish predators to examine how chemical variation in the primary producer affects these tri-trophic interactions.

The red alga Portieria hornemannii was selected for this study because it exhibits notable variation among sites in the production of secondary metabolites (Paul et al. 1987, Fuller et al. 1992, 1994, Puglisi \& Paul 1997 , Matlock et al. 1999) and is host to the sea hare Aplysia parvula (Switzer-Dunlap \& Hadfield 1977, Carefoot 1987). On Guam, the major secondary metabolite of $P$. hornemannii is apakaochtodene B (Fig. 1) which is an effective feeding deterrent against herbivores (Paul et al. 1987, 1990, 1992, Meyer et al. 1994). Several other halogenated monoterpenes including apakaochtodene A (Fig. 1), the double-bond isomer of apakaochtodene B, are minor metabolites (Paul et al. 1987, Puglisi \& Paul 1997, Gunatilaka et al. 1999, Matlock et al. 1999).

The sea hare Aplysia parvula is an oligophagous herbivore that feeds primarily on red algae (Carefoot
A.

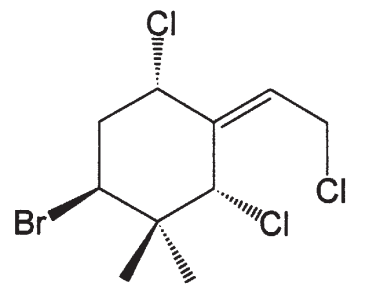

B.

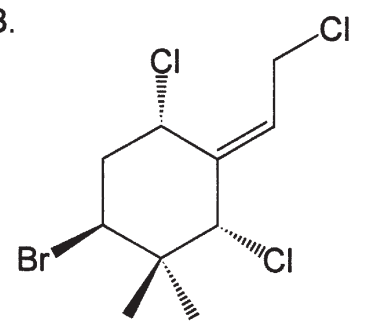

Fig. 1. Chemical structures of (A) apakaochtodene A and (B) apakaochtodene B isolated from red alga Portieria hornemannii
1987, Rogers et al. 1995) and is able to sequester algal metabolites from its diet that have been hypothesized to function in defense against predators (Faulkner 1992, de Nys et al. 1996). Switzer-Dunlap (1978) reported that, in laboratory cultures, larvae of $A$. parvula preferentially metamorphose in the presence of Portieria hornemannii (= Chondrococcus hornemanni) relative to other algae. On Guam, we have observed A. parvula to primarily live on and to preferentially graze $P$. hornemannii, from which animals sequester the algal metabolites apakaochtodene $\mathrm{A}$ and B (this study).

To investigate how seaweed chemical defenses mediate ecological interactions among the sea hare Aplysia parvula, its algal host Portieria hornemannii, and predatory reef fishes, we asked the following questions: (1) Does A. parvula prefer to consume and grow best on $P$. hornemannii compared to other algae? (2) Do among site differences in the concentrations of apakaochtodenes found in $P$. hornemannii affect the feeding behavior of $A$. parvula? (3) Are $A$. parvula (whole animals and body parts) unpalatable to reef fish predators? (4) Do the varying concentrations of apakaochtodenes found in $P$. hornemannii from different sites, which are sequestered by $A$. parvula, differentially affect predation on sea hares by reef fishes?

\section{MATERIALS AND METHODS}

Study sites and organisms. All experiments were conducted from June 1995 to June 1999 on Guam, the largest and southernmost island in the Mariana Islands archipelago located in the western North Pacific Ocean. Portieria hornemannii and Aplysia parvula were collected from 5 sites on Guam: 4 sites on the leeward side, Double Reef $\left(13^{\circ} 36^{\prime} \mathrm{N}, 144^{\circ}\right.$ $\left.48^{\prime} \mathrm{E}\right)$, Gun Beach $\left(13^{\circ} 31^{\prime} \mathrm{N}, 144^{\circ} 48^{\prime} \mathrm{E}\right)$, Apaca Point $\left(13^{\circ} 24^{\prime} \mathrm{N}, 144^{\circ} 40^{\prime} \mathrm{E}\right)$, and Anae Island $\left(13^{\circ} 23^{\prime} \mathrm{N}\right.$, $\left.144^{\circ} 38^{\prime} \mathrm{E}\right)$ and 1 site on the windward side of the

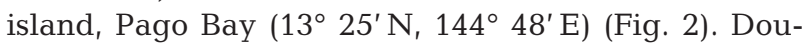
ble Reef and Gun Beach are located at the northern end of Guam. Sea hares and algae were collected from Double Reef's northeastern reef and from the northern end of Gun Beach. Pago Bay, Apaca Point and Anae Island are located further south on Guam. Samples from Pago Bay were collected behind the University of Guam Marine Laboratory and collections from Apaca Point were made from the southern end of the point. Specimens collected from Anae Island, located $\sim 450 \mathrm{~m}$ offshore, were collected from the fringing reef on its eastern side.

The alga Portieria hornemannii grows as tufts attached to rocks or dead corals in subtidal areas with 
heavy current (Trono 1969, 1997, Puglisi \& Paul 1997). Tufts are comprised of small individual thalli 3 to $9 \mathrm{~cm}$ tall with primary branches 0.5 to $1 \mathrm{~mm}$ in diameter (Trono 1969, 1997). On Guam, tufts are found 0.5 to $3 \mathrm{~m}$ apart (Puglisi and Paul 1997) and were collected haphazardly from the reef at depths of 0.5 to $8 \mathrm{~m}$.

Aplysia parvula is a small (0.4 to $10 \mathrm{~cm}$ max. length), oligophagous herbivore that feeds primarily on red algae (Carefoot 1987, Rogers et al. 1995, de Nys et al. 1996). These animals are camouflaged with coloration that matches their host algae (Rogers et al. 1995). A. parvula were obtained by collecting whole tufts of Portieria hornemannii. Bulk collections of algae, from their respective sites, were brought back to the laboratory and placed in flow-through, outdoor aquaria, under natural light for $\sim 2 \mathrm{wk}$. The handling of animals was kept to a minimum. Sea hares were gleaned from $P$. hornemannii as they were needed for each experiment.

Chemical extraction. Organic compounds were extracted from individual Portieria hornemannii thalli. Fresh or frozen whole individual thalli were rinsed quickly in freshwater to remove surface salt, cleaned of epiphytes, spun in a plastic salad spinner for 20 revolutions and blotted dry. After recording fresh weights (to the nearest $0.1 \mathrm{mg}$ ), thalli were ground with a Virtis high speed homogenizer in an equal volume solvent mixture of dichloromethane:methanol. The solvent and solid material was transferred to a beaker and the volume brought to $\sim 50 \mathrm{ml}$. After $8 \mathrm{~h}$, the extract was decanted through weighed filter paper (Whatmann GF/A Glass Microfibre filter), sealed and stored in a freezer at $-20^{\circ} \mathrm{C}$. Algal material left in the flask was resuspended in $\sim 50 \mathrm{ml}$ of fresh solvent and extracted for an additional $8 \mathrm{~h}$. Three successive extractions were performed on each sample, after which all remaining solids were dried on the filters and weighed. The combined extract from each thallus was concentrated by rotary evaporation and weighed. These crude extracts were then dissolved in hexanes, filtered through glass wool, dried, weighed, and stored at $-20^{\circ} \mathrm{C}$ prior to quantitative chemical analysis of the apakaochtodene compounds. The extract yields of individual thalli were calculated using the dry weights from filtered, crude extracts.

Monoterpenes also were extracted from Aplysia parvula. Sea hares sequester algal metabolites in their digestive gland, which is located internally and supplies enzymes to the gut. A layer of tissue called the mantle, which, in this study, includes the parapodial folds and the foot, covers the animal. Individual sea hares were frozen and either left intact, or dissected and their digestive gland and mantle removed. Because of the small size of A. parvula, it was necessary to combine replicate digestive gland and mantle parts

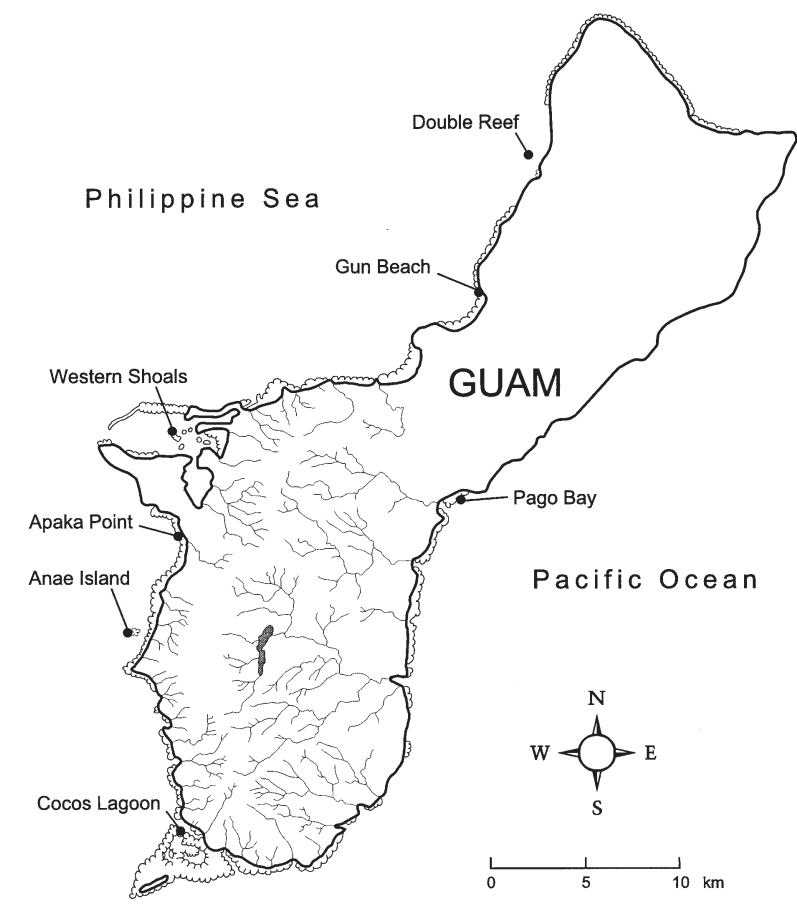

Fig. 2. Map of study sites and collection areas

(independent of one another) in order to obtain sufficient material for chemical analysis. Pooled samples were freeze dried while whole animals were stored frozen. Both pooled and whole animals were chemically extracted with acetone and prepared for analysis of apakaochtodenes as described above.

Quantitative analysis. Dried extracts for gas chromatography-mass spectrometry (gc-ms) were redissolved in hexanes with naphthalene as an internal standard at a concentration of $50 \mu \mathrm{g} \mathrm{m} \mathrm{m}^{-1}$. Samples were diluted to a concentration of $1 \mathrm{ml}$ of hexanes (with the internal standard naphthalene) per $1 \mathrm{mg}$ crude extract $\left(1 \mathrm{mg} \mathrm{ml}^{-1}\right.$ ). Gas chromatography was conducted using a Hewlett-Packard 5980 Series II Plus gas chromatograph with a cross-linked 5\% methyl silicone column (HP-5, $30 \mathrm{~m} \times 0.25 \mathrm{~mm})$. Injections were made in the splitless mode with an inlet pressure of $13.9 \mathrm{kPa}$ at $70^{\circ} \mathrm{C}$. The injection port was held at $250^{\circ} \mathrm{C}$ with a 70 to $290^{\circ} \mathrm{C}$ temperature ramp at $10^{\circ} \mathrm{C}$ $\mathrm{min}^{-1}$. The carrier gas was helium at a flow rate of

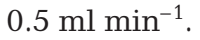

Mass spectrometry was conducted with an HP 5972 Mass Selective Detector (MSD). Ions characteristic of the internal standard naphthalene and apakaochtodenes $\mathrm{A}$ and $\mathrm{B}$ were monitored in the selected ion monitoring (SIM) mode and were quantitatively analyzed using purified standards. Quantification was performed with a multiple point (6 dilutions) external method using the HP ChemStation (1993) software. 
The peak areas of apakaochtodenes A, B and the internal standard naphthalene were measured and their ratio (compound:internal standard) calculated and converted to concentration by reference to standard curves specific to each pure compound. For both apakaochtodenes A and B, the amount of pure compound was converted to \% yield based on total dry mass of the individual thallus or sea hare.

Choice assays. The dietary preferences of Aplysia parvula were determined by conducting choice assays in laboratory aquaria (Paul \& Pennings 1991). A. parvula used in each set of choice assays were collected from either Apaca Point or Gun Beach. Animals ( $\mathrm{n}=8$ to 15 ) were placed individually in separate 11 flow-through aquaria $($ diam. $=16 \mathrm{~cm}$, max. depth $=$ $8 \mathrm{~cm}$ ). Each sea hare was offered a choice between 2 species of algae that were weighted with clothespins at opposite ends of the aquarium. Individual sea hares were placed in the middle of each aquarium at the beginning of the experiment and their presence or absence on either of the 2 algae was recorded hourly for 4 to $6 \mathrm{~h}$. Following the methods of Paul \& Pennings (1991), individual animals were excluded from the experiment if they were not recorded on algae at least 3 times. Individual sea hares were used only once during the experiment. Five separate choice tests were conducted: Portieria hornemannii vs Acanthopora spicifera; P. hornemannii vs Asparagopsis taxiformis; $P$. hornemannii vs Dictyota cervicornis; $P$. hornemannii vs Galaxaura marginata; P. hornemannii vs Gracilaria tsudae; and P. hornemannii vs Laurencia papillosa. Sea hares were recorded as choosing the alga upon which they were observed the most (ties were excluded). For each choice assay, the total number of animals that chose 1 seaweed compared to another was analyzed using a 2-tailed binomial test. These particular seaweeds, all of which are red algal species except the brown alga Dictyota cervicornis, were used in choice and no-choice (below) assays because they are among the most common seaweeds in habitats where $A$. parvula is found on Guam.

No-choice assays. No-choice assays were based on Aplysia parvula growth and consumption on 5 separate, single species, algal diets: Laurencia papillosa, Dictyota cervicornis, Gracilaria tsudae, Acanthophora spicifera, or Portieria hornemannii (Paul \& Pennings 1991).

Sea hares were blotted dry and weighed (to the nearest $0.1 \mathrm{mg}$ ). After confirming that there were no significant differences among the initial weights of animals (1-way ANOVA, $F_{4,42}=0.36, p=0.83$ ), each algal species was provided ad libitum to individual sea hares $(\mathrm{n}=10) \mathrm{kept}$ in separate $250 \mathrm{ml}$ flow-through aquaria (diam. $=7 \mathrm{~cm}$, max. depth $=9 \mathrm{~cm}$ ). After $6 \mathrm{~d}$, each animal was weighed again and its relative change in mass was calculated using the following equation: $\left[\left(T_{\mathrm{f}}-T_{\mathrm{o}}\right) / T_{\mathrm{o}}\right]$, where $T_{\mathrm{o}}$ and $T_{\mathrm{f}}$ are the weight of $A$. parvula before and after the assay. Growth rates were $\log (x+2)$ transformed to meet parametric criteria, slopes were compared by ANCOVA with the initial weights of $A$. parvula held as the covariate, and means were compared using Tukey's HSD pairwise comparisons test.

During the growth assays described above, measurements of the consumption of algae by Aplysia parvula were also conducted. Following the protocol suggested by Peterson \& Renaud (1989) and modified by Cronin \& Hay (1996b), each algal species (see above) was divided into replicate treatments and no-herbivore controls. Each replicate sample was blotted dry and weighed on an electronic balance (to the nearest $0.1 \mathrm{mg}$ ). No-herbivore controls were used to control for autogenous changes in mass in the absence of herbivores. After $6 \mathrm{~d}$, each alga was reweighed and the amount of algal tissue consumed by sea hares was calculated after correcting for autogenous weight changes in seaweeds using the following equation: $\left[\left(T_{\mathrm{o}} \times C_{\mathrm{f}} / C_{\mathrm{o}}\right)-T_{\mathrm{f}}\right]$, where $T_{\mathrm{o}}$ and $T_{\mathrm{f}}$ are the weight of the algal pieces exposed to herbivory before and after the assay, and $C_{\mathrm{o}}$ and $C_{\mathrm{f}}$ are the weight of the controls for autogenic changes before and after the assay (Cronin \& Hay 1996b). Consumption data could not be transformed to meet parametric criteria. Consequently, the non-parametric Kruskal-Wallis test was used to test for differences in mean consumption rates among the 5 seaweed diets. The non-parametric equivalent of Tukey's HSD test was used to assess differences among means.

Whole samples of the seaweeds Acanthophora spicifera, Dictyota cervicornis, Gracilaria tsudae, Laurencia papillosa, and Portieria hornemannii were analyzed for total Kjeldahl nitrogen (TKN) (Lachat Instruments 1992) and organic carbon (Nelson \& Sommers 1975) using a Lachat QuickChem Automated Ion analyzer. Portions of each algal thallus $(n=3)$ were rinsed in seawater to remove extraneous material, oven dried at $62^{\circ} \mathrm{C}$ for $48 \mathrm{~h}$ and stored at $-20^{\circ} \mathrm{C}$ in tightly capped vials. TKN and organic carbon data were calculated as the \% yield of nitrogen and carbon from total dry mass of the seaweed. TKN values present in different species of seaweed were arcsinsquareroot transformed to meet parametric criteria. Organic Carbon and TKN data were analyzed by 1-way ANOVA and means were compared using Tukey's HSD multiple comparisons test.

Chemical bioassays. Crude Portieria hornemannii extract and pure apakaochtodenes were tested at varying concentrations to determine their effects on feeding by Aplysia parvula. Mean natural wet mass concentrations of $P$. hornemannii crude extract were 
between 0.5 to $4 \%$. Conversely, pure apakaochtodenes were approximately $10 \%$ of the crude extract and natural wet mass concentrations ranged from 0.01 to $0.6 \%$. Thalli of the palatable red seaweed Acanthophora spicifera (5 to $7 \mathrm{mg}$ wet mass) were trimmed with a razor blade to a length of $5 \mathrm{~cm}$ and coated with a solution of either crude $P$. hornemannii extract or pure apakaochtodene A or B dissolved in hexanes (Hay et al. 1998). Treated thalli were tested over a range of concentrations that approximate their natural wet mass concentrations. Controls consisted of A. spicifera thalli that were coated with hexanes only. Since metabolites extracted from $P$. hornemannii are lipidsoluble, they adhere to the surface of the A. spicifera thalli after the hexanes evaporate. Hay et al. (1998) found that lipid soluble metabolites from other seaweeds were not lost after $24 \mathrm{~h}$ underwater in similar experiments. For each assay, individual sea hares ( $\mathrm{n}=$ 10) were given a choice between treated and control A. spicifera thalli offered simultaneously. Bioassays were run as described previously (Choice assays) over an interval of 24 to $48 \mathrm{~h}$. The amount (in $\mathrm{cm}$ ) of treated and control $A$. spicifera thalli eaten by each sea hare was recorded and analyzed using a paired $t$-test. Controls for autogenous changes in mass in the absence of herbivores were not necessary for this experiment because the length of $A$. spicifera thalli did not change without herbivory.

Chemical variation among sites. The preference of Aplysia parvula for Portieria hornemannii collected from different locations was determined using choice assays in laboratory aquaria. P. hornemannii was collected from different sites around Guam, and each population was held in a separate tank. Individual sea hares ( $\mathrm{n}=10$ to 15 ), collected at Gun Beach, were placed in $1 \mathrm{l}$ flow-through aquaria and offered a choice between individual $P$. hornemannii thalli from 2 different sites. Choice assays using A. parvula were run as described previously (Choice assays) and were recorded hourly for 5 to $7 \mathrm{~h}$. Three separate choice experiments were conducted for the $P$. hornemannii (different populations are listed by site): Apaca Point vs Double Reef; Pago Bay vs Apaca Point; and Pago Bay vs Double Reef. Assays testing algae from Apaca Point vs Pago Bay were conducted on 2 separate d using different sea hares on each day. The assay results from these $2 \mathrm{~d}$ were combined and used as replicates. For each choice assay, the total number of animals choosing one population of $P$. hornemannii compared to another was analyzed using a 2-tailed binomial test. Additionally, individual P. hornemannii were collected separately from Apaca Point $(\mathrm{n}=7)$, Double Reef $(n=6)$ and Pago Bay $(n=7)$, and chemically analyzed by gc-ms for their concentrations of apakaochtodenes A and B. Apakaochtodene A data could not be transformed to meet parametric criteria. Thus, the non-parametric Kruskal-Wallis test was used to test for differences in the levels of apakaochtodene A among the $P$. hornemannii populations. The nonparametric equivalent of Tukey's HSD test was used to assess for differences among means. Differences in the levels of apakaochtodene B among the populations of $P$. hornemannii were analyzed by 1-way ANOVA followed by Tukey's HSD multiple comparisons test. Sea hares were also collected at Anae Island $(\mathrm{n}=11)$ and Double Reef $(\mathrm{n}=10)$ and were analyzed chemically by gc-ms. These data, however, could not be transformed to meet parametric criteria. The apakaochtodene A and $\mathrm{B}$ contents of sea hares were compared between the 2 sites using the non-parametric Mann-Whitney test.

Palatability to predators. Sea hares and other opisthobranch molluscs can be preyed upon by fish, crustaceans, and even other opisthobranchs (Carefoot 1987, Pennings 1990a, Avila \& Paul 1997, Gochfeld \& Aeby 1997, Johnson \& Willows 1999). In tropical habitats, coral reef fishes may be particularly important at controlling populations of opisthobranch molluscs (Gochfeld \& Aeby 1997). We tested the palatability of Aplysia parvula to reef fish predators because these assays could be done in the field with natural assemblages of reef fishes.

The palatability of Aplysia parvula to reef fishes was determined at 2 sites on Guam: Gun Beach and Western Shoals (Paul \& Pennings 1991). At both sites, frozen, whole $A$. parvula collected from Anae Island ( $\mathrm{n}=10$ to 12 ) and Double Reef ( $\mathrm{n}=10$ to 11 ) were released in random order into the water column by a scuba diver $\sim 4 \mathrm{~m}$ below the surface. The fate of each animal (rejected or eaten) after $\sim 30 \mathrm{~s}$ exposure to fish predation was recorded by a second diver underwater. At Western Shoals, live A. parvula from Anae Island $(\mathrm{n}=10)$ were also tested to determine if ink and/or mucus secretions affected feeding by fish. Chunks of squid $(\mathrm{n}=10)$, cut into pieces comparable to whole sea hares, served as controls to ensure that fish were readily feeding. A $G$-test of independence was used to analyze results via a $3 \times 2$ contingency table for Gun Beach and a $4 \times 2$ contingency table for Western Shoals.

Aplysia parvula from Apaca Point $(\mathrm{n}=10)$ and Double Reef $(n=10)$ were frozen, dissected, and their body parts (digestive gland and mantle) offered to reef fishes at Gun Beach. Digestive gland $(\mathrm{n}=10)$ and mantle $(\mathrm{n}=10)$ parts were removed from each animal and treated as independent replicates. Body parts and squid chunks ( $\mathrm{n}=10$, fish feeding controls) were cut into equal-sized pieces and released in random order into the water column as described above. Assays were analyzed using a 3-way log-linear model, classifying responses based on site of collection (Apaca Point or 
Double Reef), type of body part (digestive gland or mantle), and number of body parts eaten or rejected. Selective feeding on digestive gland and mantle from Apaca Point and Double Reef was analyzed for each site using Fisher's Exact Test. It was not possible, however, to collect a sufficient number of A. parvula from either Apaca Point or Double Reef for chemical analysis. Thus, sea hares were collected from Cocos Lagoon. The chemical content of animals collected from this site is similar to animals from Apaca Point and Double Reef. Sea hares $(n=10)$ were frozen, dissected and their digestive gland and mantle parts chemically analyzed by gc-ms for their apakaochtodene A and B content.

Individual sea hares maintained in laboratory aquaria on Portieria hornemannii ( $\mathrm{n}=15$, from Double Reef) and the red alga Acanthophora spicifera ( $\mathrm{n}=15$, from Pago Bay) were offered to reef fishes at Western Shoals. While Aplysia parvula is not commonly found on A. spicifera on Guam, animals were found once on this alga, which is known to contain no unpalatable secondary metabolites. We have no data to suggest that the A. parvula found on A. spicifera had ever eaten $P$. hornemannii. Sea hares and squid chunks (n = 15, fish feeding controls) were released in random order into the water column as described previously, and the fate of each animal was recorded underwater. Assays were analyzed using a G-test of independence via $2 \times 2$ contingency table; results were based on the sea hare's algal diet (A. spicifera or $P$. hornemannii) and whether sea hares were eaten or rejected. $A$. parvula that were rejected by fishes in the field were analyzed chemically by gc-ms. The apakaochtodene A and B contents of sea hares maintained on $P$. hornemannii were compared to those maintained on A. spicifera using the non-parametric Mann-Whitney test.

Table 1. Dietary preferences of Aplysia parvula for different algal species. $\mathrm{p}$ values determined with binomial test (2-tailed)

\begin{tabular}{|lccc|}
\hline Alga & $\begin{array}{c}\text { Sample } \\
\text { size }\end{array}$ & $\begin{array}{c}\text { No. of } \\
\text { preferring }\end{array}$ & $\mathrm{p}$ \\
\hline Portieria hornemannii & 10 & 7 & 0.015 \\
Acanthophora spicifera & & 0 & \\
P. hornemannii & 12 & 10 & 0.002 \\
Asparagopsis taxiformis & & 0 & \\
P. hornemannii & 12 & 8 & 0.007 \\
Dictyota cervicornis & & 0 & \\
P. hornemannii & 11 & 10 & 0.002 \\
Galaxaura marginata & & 0 & \\
P. hornemannii & 10 & 9 & 0.021 \\
Gracilaria tsudae & & 1 & \\
P. hornemannii & 8 & 8 & 0.007 \\
Laurencia papillosa & & 0 & \\
\hline
\end{tabular}

\section{RESULTS}

\section{Choice assays}

Aplysia parvula chose Portieria hornemannii over all other tested seaweeds including the red algae Acanthophora spicifera, Asparagopsis taxiformis, Galaxaura marginata, Gracilaria tsudae, Laurencia papillosa, and the brown alga Dictyota cervicornis (2-tailed binomial, $\mathrm{p}<0.05$; Table 1). Of all choice tests performed, only one individual $A$. parvula preferred an alga other than P. hornemannii, and it chose G. tsudae.

\section{No-choice assays}

The relative change in mass of Aplysia parvula maintained on the 5 seaweed diets differed significantly over the 7 -d period (ANCOVA, $F_{4,41}=12.07, \mathrm{p}<$ 0.001; Fig. 3a). During these assays, 3 sea hares died
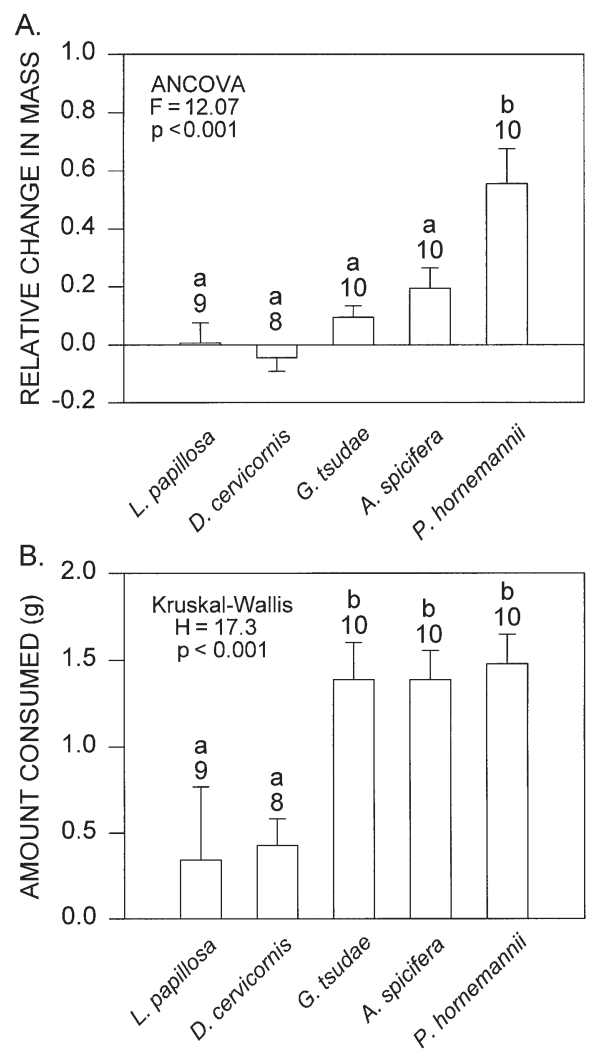

Fig. 3. Aplysia parvula. No-choice assays for 5 algal diets. (A) Mean relative change in mass and (B) amount of algae consumed by individual sea hares (+ $1 \mathrm{SE}$ ). Relative changes in mass values $\log (x+2)$ transformed before ANCOVA. Identical letters above bars indicate means not different ( $p>0.05)$. Numbers above bars represent number of samples analyzed. In (A), pairwise comparisons made using Tukey's HSD; in (B), non-parametric equivalent of Tukey's HSD used. Untransformed means presented for clarity 


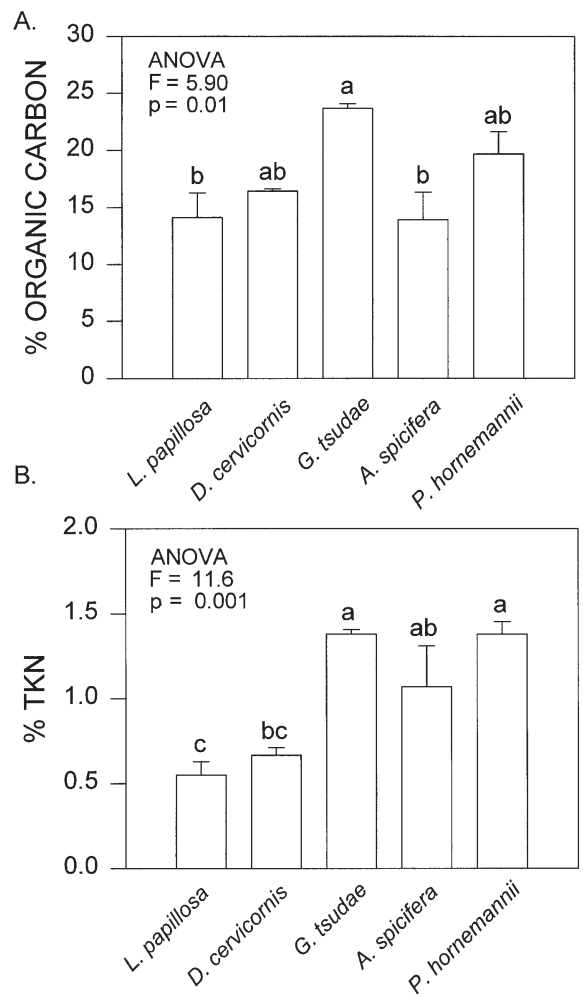

Fig. 4. Organic carbon and TKN (total Kjeldahl nitrogen) content of 5 algal diets. (A) Mean \% organic carbon and (B) mean $\%$ TKN (+1 $\mathrm{SE}_{;} \mathrm{n}=3$ for each algal treatment). TKN values arcsin-squareroot transformed. Organic carbon and TKN data converted to \% yield based on total dry mass of seaweed. Identical letters above bars indicate means are not different ( $p$ > 0.05). Pairwise comparisons made using Tukey's HSD. Untransformed means presented for clarity

(1 fed Laurencia papillosa; 2 fed Dictyota cervicornis) and were excluded from the experiment. Individual sea hares grew best on Portieria hornemannii compared with all other tested seaweeds. The amount of algae consumed by $A$. parvula also was significantly different among treatments (Kruskal-Wallis, $\mathrm{H}=17.30$, $\mathrm{df}=4, \mathrm{p}<0.001$; Fig. 3b). Sea hares consumed significantly greater amounts of Gracilaria tsudae, Acanthophora spicifera and P. hornemannii than L. papillosa or D. cervicornis.

The mean amounts of organic carbon and total Kjeldahl nitrogen (TKN) differed significantly within the 5 seaweeds analyzed (ANOVA, $F_{4,10}=5.90, \mathrm{p}=0.01$, and $F_{4,10}=11.67, p=0.001$, respectively; Fig. $\left.4 \mathrm{a}, \mathrm{b}\right)$. Despite significant differences among algal treatments, high levels of organic carbon were present in all of the seaweeds analyzed (Fig. 4a). The amounts of TKN in the different algae were more variable and reached their highest levels in Gracilaria tsudae, Acanthophora spicifera and Portieria hornemannii and their lowest levels in Laurencia papillosa and Dictyota cervicornis (Fig. 4b).

\section{Chemical bioassays}

While crude Portieria hornemannii extract did not significantly deter feeding by $A$. parvula at concentrations $\leq 2 \%$ of algal wet mass (paired $t$-test, $\mathrm{p}>0.05$ ), feeding was deterred at concentrations of $4 \%$ and $6 \%$ (paired $t$-test, $\mathrm{p}<0.05$ ) (Fig. 5a). In a direct comparison, sea hares did not significantly distinguish (paired $t$-test, $\mathrm{p}=0.39$ ) between the crude $P$. hornemannii extract $(0.9 \%$ wet mass $)$ from Anae Island and Gun Beach (Fig. 5b). Both apakaochtodenes A and B, at all concentrations tested, significantly deterred (paired $t$-test, $\mathrm{p}<0.05$ ) feeding by sea hares (Fig. $6, \mathrm{~b}$ ).

\section{Among site chemical variation}

In choice assays, individual Aplysia parvula did not show a significant preference for Portieria hornemannii collected from Apaca Point, Double Reef or Pago Bay (2-tailed binomial, $\mathrm{p}>0.05$; Table 2). Chemical

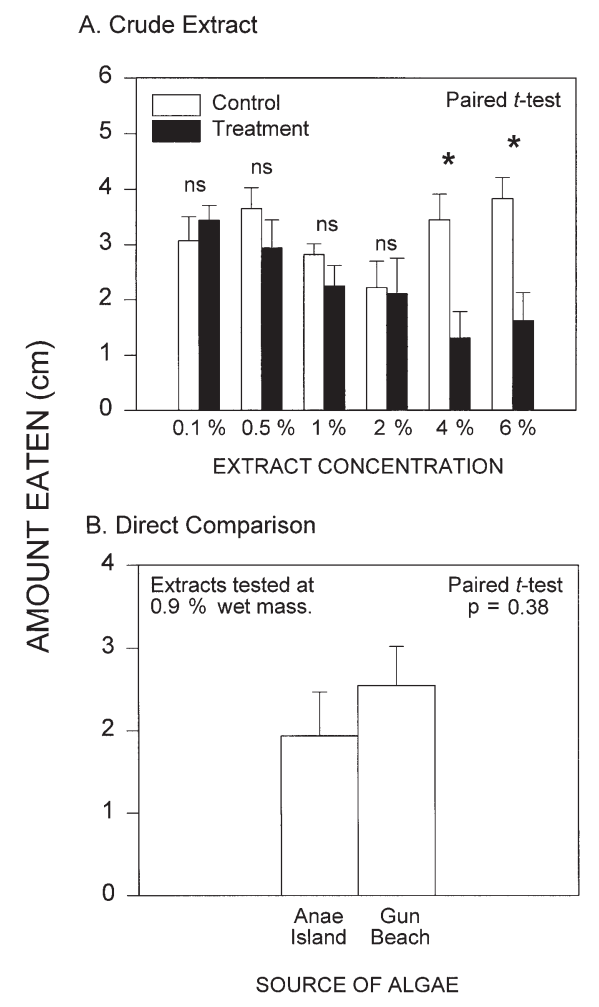

Fig. 5. Aplysia parvula. Chemical bioassays using crude extracts from red alga Portieria hornemannii. (A) Crude extracts tested at wet mass concentrations that span the natural range of concentrations found in alga and (B) in direct comparison between $P$. hornemannii from 2 different locations: Anae Island; Gun Beach. Data represent mean amount of Acanthophora spicifera eaten $\left(+1 \mathrm{SE}_{;} \mathrm{n}=10\right.$ paired replicates for each comparison). *values differed significantly ( $p<0.05)$ between controls and treatments for a given extract concentration. ns: means did not differ significantly $(p>0.05)$ 


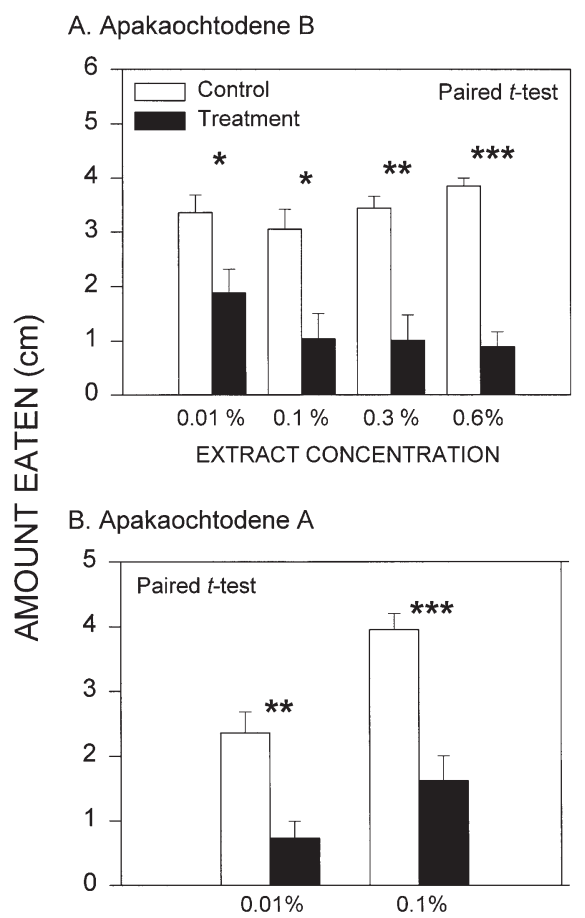

Fig. 6. Aplysia parvula. Chemical bioassays using pure compounds from red alga Portieria hornemannii. (A) Apakaochtodene B and (B) apakaochtodene A tested at wet mass concentrations that span natural range of concentrations found in alga. Data represent mean amount of Acanthophora spicifera eaten $(+1 \mathrm{SE} ; \mathrm{n}=10$ paired replicates for each comparison). ${ }^{*},{ }^{* *}$ and ${ }^{* * *}$ values differed significantly ( $\mathrm{p}<0.05$, $\mathrm{p}<0.01$ and $\mathrm{p}<0.001$, respectively) between controls and treatments for a given extract concentration

analysis by gc-ms indicated significant differences in the levels of apakaochtodene A and B within individual algae among sites (Kruskal-Wallis test, $\mathrm{H}=14.03$, $\mathrm{df}=2, \mathrm{p}<0.001$, and ANOVA, $F_{2,17}=6.60, \mathrm{p}=0.007$, respectively; Fig. 7a). Mean levels of apakaochtodenes A and B were significantly higher in thalli from Apaca Point compared to Double Reef and Pago Bay, while there was no difference between thalli from Double Reef or Pago Bay.

Table 2. Dietary preferences of Aplysia parvula for Portieria hornemannii collected from different sites. $p$ values were determined with a binomial test (2-tailed)

\begin{tabular}{|lccc|}
\hline Site & Sample size & No. of preferring & $\mathrm{p}$ \\
\hline Apaca Point & 13 & 10 & 0.092 \\
Double Reef & & 3 & \\
Pago Bay & 10 & 6 & 0.507 \\
Double Reef & & 3 & \\
Apaca Point & 15 & 8 & 0.387 \\
Pago Bay & & 4 & \\
\hline
\end{tabular}

Chemical analysis of Aplysia parvula showed that animals from Anae Island sequestered significantly greater levels of apakaochtodenes A and B than those from Double Reef (Mann-Whitney test, $U=110.0$, $\mathrm{p}<$ 0.001 , and $U=84.0, \mathrm{p}=0.044$, respectively; Fig. $7 \mathrm{~b}$ ).

\section{Palatability to predators}

In field assays at Gun Beach and Western Shoals, neither frozen sea hares from Anae Island nor Double Reef were palatable to reef fishes compared with squid pieces ( $G$-test, $G=31.60, \mathrm{df}=2, \mathrm{p}<0.001$, and $G=9.21$, $\mathrm{df}=3, \mathrm{p}<0.01$, respectively; Fig. 8a). At Gun Beach, the fishes Thalassoma lutescens, Halichores hortulanus, and Balistapus undulatus ate frozen sea hares. Conversely, at Western Shoals, the fishes Scarus sp. and Naso vlamingii ate frozen sea hares, however, no

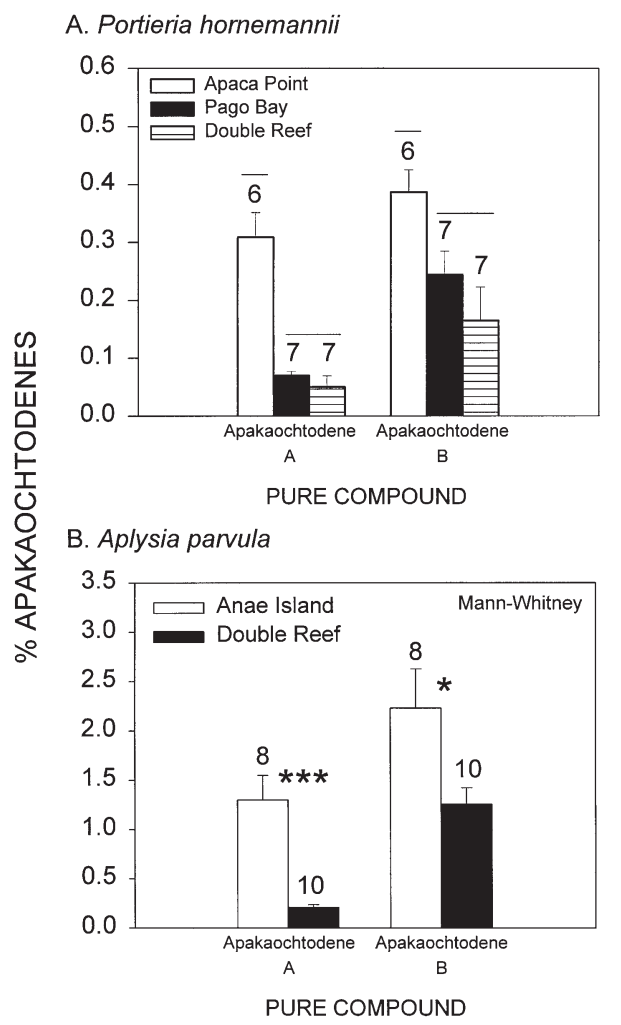

Fig. 7. Among site chemical variation of apakaochtodenes in (A) red alga Portieria hornemannii and (B) sea hare Aplysia parvula. Amounts of apakaochtodenes A and B converted to $\%$ yield based on total dry mass of algae and sea hares. Data represent mean \% apakaochtodenes (+1 SE). Numbers above bars represent number of samples analyzed. In (A), pairwise comparisons were made among the amounts of apakaochtodenes A and B using non-parametric equivalent of Tukey's HSD, and Tukey's HSD, respectively. Horizontal bars connect means that are not significantly different $(p>0.05)$. In (B), * and ${ }^{* * *}$ values differed significantly $(U=84, \mathrm{p}<0.05$ and $U$ $=110.0, \mathrm{p}<0.001$, respectively) among sites for a given pure compound 
live sea hares were eaten. For nearly all cases, sea hares were eaten only after being mouthed and released by numerous fishes.

Field assays at Gun Beach also indicated that digestive gland and mantle parts from Aplysia parvula were not palatable to reef fishes (Fig. 8b). Reef fishes readily consumed squid parts. However, so as not to confound the specific question of the palatability of $A$. parvula body parts from different sites, squid data were excluded from statistical analyses. Since a log-linear model including all possible 2-way interactions did not significantly fit the observed preference data $(G=4.54$, $\mathrm{df}=1, \mathrm{p}=0.033$ ), a 3 -way interaction must be used to account for this variation. Fishes ate similar amounts of digestive gland parts from Apaca Point (1 eaten: 9 rejected) and Double Reef (0:10), whereas, fish ate different amounts of mantle parts from Apaca Point

\section{A. Whole Animals}

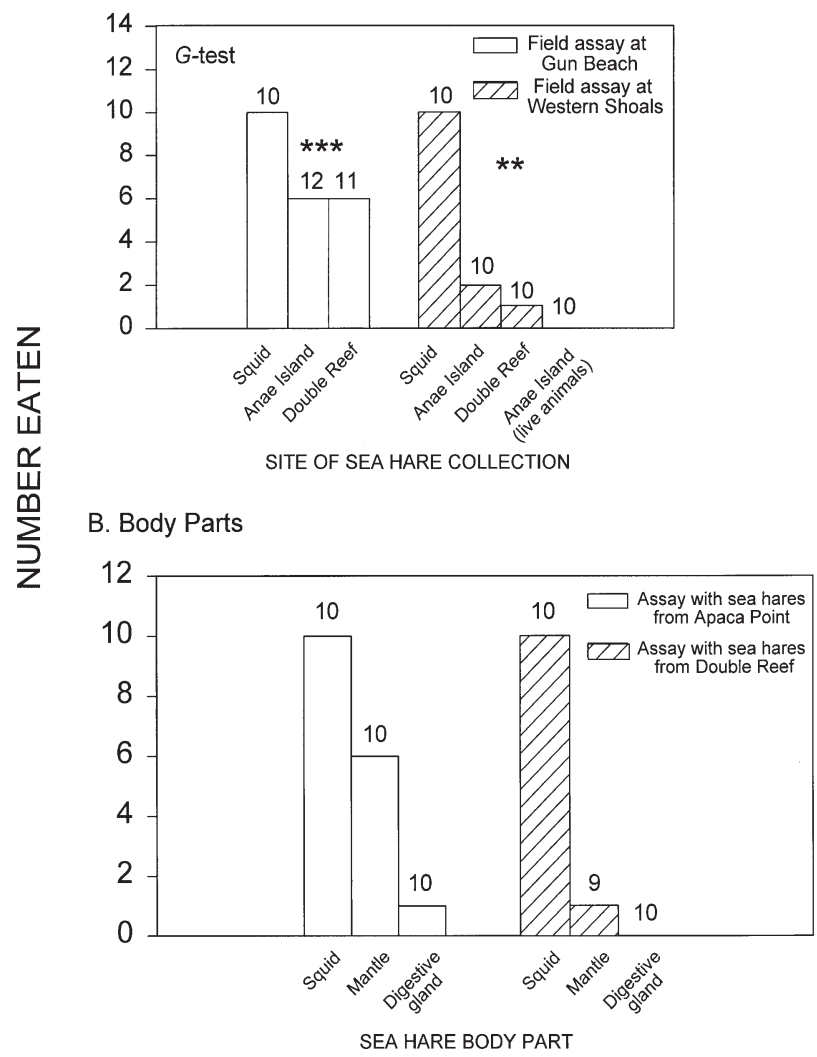

Fig. 8. Aplysia parvula. Palatability of (A) whole sea hares and (B) their body parts to reef fishes. Data represent number of whole animals or body parts eaten by reef fishes. Palatability of whole animals at Gun Beach and Western Shoals analyzed using a $3 \times 2$ and $4 \times 2$ contingency table, respectively. Body parts analyzed using a 3-way log-linear model. Chunks of squid served as fish feeding controls. Numbers above bars represent number of samples analyzed. ${ }^{* *}$ and ${ }^{* * *}$ values differed significantly $(G=31.6, p<0.01$ and $G=9.21, p<0.001$, respectively) among sea hares collected from different sites and squid pieces

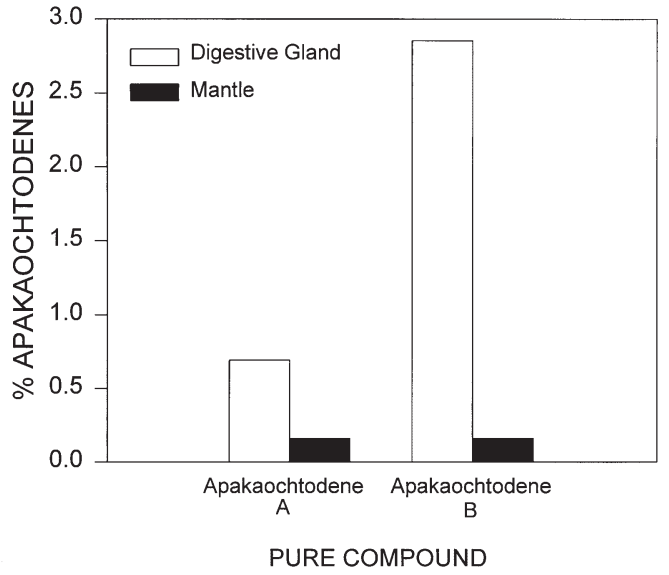

Fig. 9. Aplysia parvula. Apakaochtodene content of digestive gland and mantle parts. Whole sea hares $(n=10)$ dissected and their digestive gland and mantle parts removed. Body parts combined to obtain sufficient material for chemical analysis (digestive gland; $\mathrm{n}=1$ and mantle; $\mathrm{n}=1$ ). Data represent mean \% apakaochtodenes. Amounts of apakaochtodenes $\mathrm{A}$ and $\mathrm{B}$ converted to \% yield based on total dry mass of sea hare body parts

(6:4) and Double Reef (1:9). The fishes Abudefduf saxatilis, Thalassoma lutescens and Arothron manilensis consumed both types of sea hare body parts. Chemical analysis by gc-ms indicated that levels of apakaochtodenes $\mathrm{A}$ and $\mathrm{B}$ were higher within the digestive gland of A. parvula compared with its mantle (Fig. 9).

Reef fishes significantly preferred whole Aplysia parvula found on Acanthophora spicifera compared with sea hares found on Portieria hornemannii (G-test, $G=9.19, \mathrm{df}=1, \mathrm{p}=0.002$; Fig. 10a). Squid data were excluded from statistical analyses, as described above. Chemical analysis of $A$. parvula not eaten by fishes in the field showed that the apakaochtodene A and B content of sea hares found on $P$. hornemannii was significantly higher than animals found on A. spicifera (Mann-Whitney test, $U=67.5, \mathrm{p}=0.003$ and $U=70.0$, $\mathrm{p}=0.001$, respectively; Fig. 10b).

\section{DISCUSSION}

\section{Dietary specialization}

On Guam, Aplysia parvula chose and exhibited better growth on Portieria hornemannii over all other seaweed diets tested. While sea hares consumed algae that contained similar amounts of organic carbon and TKN, the relative growth of animals was greatest when they consumed $P$. hornemannii. Similarly, in other areas of the Pacific, A. parvula consumes a variety of red algae that are rich in secondary metabolites (Carefoot 1987, Rogers et al. 1995), many of which contain 

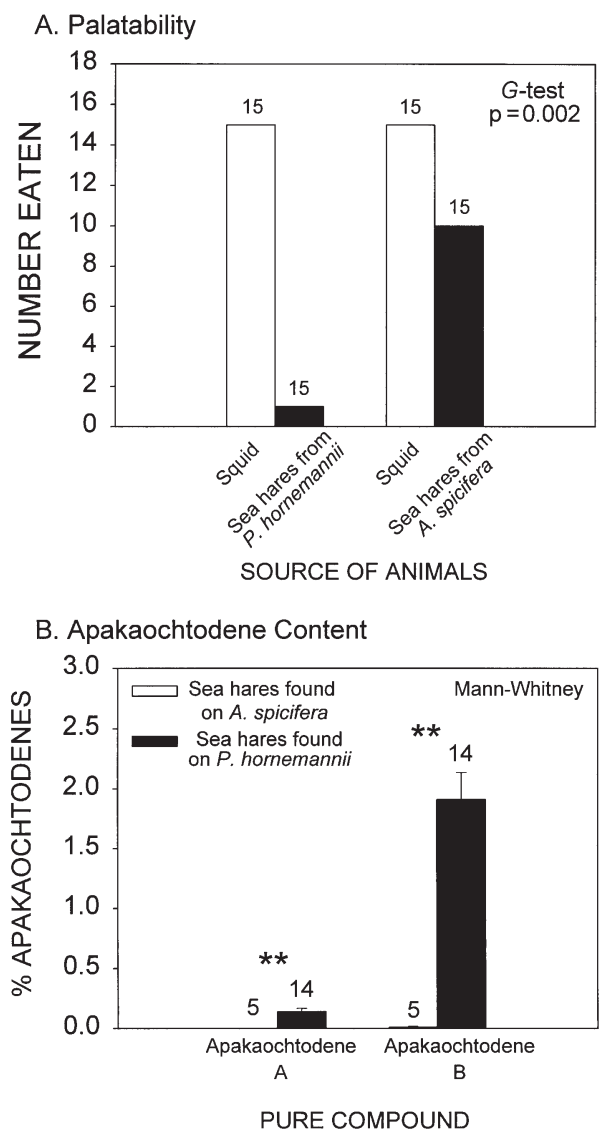

Fig. 10. Aplysia parvula. (A) Palatability and (B) apakaochtodene content of sea hares found on either red alga Portieria hornemannii or Acanthophora spicifera. Palatability data represent number of animals eaten by reef fishes at Western Shoals and were analyzed using a $2 \times 2$ contingency table. Chunks of squid served as fish feeding controls. Chemical data indicate mean \% apakaochtodenes ( $+1 \mathrm{SE})$. Amounts of apakaochtodenes A and B converted to \% yield based on total dry mass of sea hares. Numbers above bars represent number of samples analyzed. ${ }^{* *}$ values differed significantly ( $U=67.5$, $\mathrm{p}=0.003$ and $U=70.0, \mathrm{p}=0.001$, respectively) between sea hares found on $P$. hornemannii compared to A. spicifera

halogenated secondary metabolites (Hay \& Fenical 1988). For example, in New South Wales, Australia, Rogers et al. (1995) reported that $A$. parvula preferentially consumes the nutritionally and chemically rich red algae Laurencia obtusa and Delisea pulchra, which are its primary algal hosts. Surprisingly, however, sea hares did not grow when fed D. pulchra, from which animals sequester secondary metabolites that are unpalatable to reef fishes (de Nys et al. 1996), but grew best on L. obtusa. The dietary preferences of herbivores and the nutritional content of the seaweed species that they consume are often unrelated (Carefoot 1987, Duffy \& Hay 1991, Rogers et al. 1995, Wakefield \& Murray 1998). Indeed, feeding specialization by $A$. parvula on chemically defended algae may reflect their need for algal hosts to serve as refuges against predation rather than some unique dietary requirement (Futuyma \& Moreno 1988, Pennings 1990a, Rogers et al. 1995, Wakefield \& Murray 1998).

Aplysia parvula may become less susceptible to predation by selectively living and feeding on Portieria hornemannii. The major secondary metabolite produced by this alga is apakaochtodene B which is an effective feeding deterrent to herbivorous fishes (Paul et al. 1987, 1990, 1992, Meyer et al. 1994). Therefore, $P$. hornemannii may offer $A$. parvula 'enemy-free space' (Price et al. 1980, Jeffries \& Lawton 1984); that is, sea hares may avoid being eaten by inhabiting an alga that its predators (e.g., reef fishes) avoid (Rogers et al. 1995). These results are consistent with other studies of alga-mesograzer-predator interactions and support the hypothesis that mesograzers can minimize predation by specializing on chemically defended seaweeds that are unpalatable, and thus approached less by fish predators (Hay et al. 1987, 1989, 1990a,b, Hay \& Fenical 1988, Duffy \& Hay 1991, 1994, Paul \& Pennings 1991, Hay \& Steinberg 1992, de Nys et al. 1996).

Dietary specialization by Aplysia parvula may also be influenced by the types and concentrations of algal secondary metabolites found in its host algae. As previously mentioned, the work of Rogers et al. (1995) with A. parvula in Australia suggested that sequestration of secondary metabolites from the red alga Delisea pulchra might restrict sea hare's growth. On Guam, A. parvula encountered individual Portieria hornemannii thalli that contain crude extract concentrations ranging from 0.5 to $4 \%$ of algal wet mass. At low concentrations, crude extract had little effect on sea hare grazing, but it deterred feeding at higher concentrations. Crude extract was a deterrent at $4 \%$, a concentration found to be present in $\leq 2 \%$ of individual P. hornemannii thalli collected from several different locations on Guam (Matlock et al. unpubl. data). These findings are consistent with previous studies reporting that it is not uncommon for mesograzers, who by definition both live and feed on their host alga, to be indifferent to low concentrations of seaweed chemical defenses, yet be deterred at higher concentrations of these same metabolites (Hay et al. 1989, 1990, Pennings \& Paul 1993, Steinberg 1995, Hay 1996, Nagle et al. 1998).

In contrast, the pure apakaochtodene A and B compounds produced by Portieria hornemannii, significantly deterred feeding by Aplysia parvula at all concentrations tested (Fig. 6); a surprise, considering that sea hares were indifferent to equivalent proportions of crude $P$. hornemannii extract. The underlying causes of this disparity between the ability of crude extract and apakaochtodenes to deter feeding by sea hares are not known. It is possible that compounds such as 
triglycerides or sterols within the crude extract of $P$. hornemannii mask the potency of apakaochtodenes $\mathrm{A}$ and $\mathrm{B}$. Another factor may be that pure compounds were applied to the surface of Acanthophora spicifera thalli, which is probably not where the monoterpenes are located in live $P$. hornemannii.

Portieria hornemannii shows significant variation in apakaochtodene content among thalli within the same site (Matlock et al. 1999). It is possible that such differences in the chemical makeup of $P$. hornemannii may present a problem to Aplysia parvula in that its algal host may vary in its suitability as a resource both temporally and spatially (Nagle et al. 1998, Matlock et al. 1999).

Despite among-site differences in levels of apakaochtodenes A and B, Aplysia parvula showed no significant preference for Portieria hornemannii from any location (Fig. 7, Table 2). These results are consistent with previous studies that have demonstrated significant variation in the production of apakaochtodenes by $P$. hornemannii among different locations on Guam (Puglisi \& Paul 1997, Matlock et al. 1999). Our data suggest that at the site level, the feeding behavior of $A$. parvula was not influenced by the composition or concentration of apakaochtodenes produced by $P$. hornemannii, and are consistent with findings by Steinberg (1995), where feeding by the herbivorous sea urchin Holopneustes purpurescens was not affected by variation in levels of phlorotannins in its host kelp Ecklonia radiata.

\section{Predation on Aplysia parvula}

Similar to other sea hares (Faulkner 1992, Pennings 1994, Johnson \& Willows 1999), Aplysia parvula sequesters diet-derived chemical defenses from its host algae (Rogers et al. 1995, de Nys et al. 1996), which on Guam is Portieria hornemannii. Our field experiments indicated that sea hares found on $P$. hornemannii, regardless of where they were collected, were unpalatable to reef fish. Thus, despite differences in the composition and concentrations of apakaochtodenes in $P$. hornemannii among sites, A. parvula that fed on $P$. hornemannii from Apaca Point were no more vulnerable to predation than when they had fed on $P$. hornemannii from Double Reef. The fish species found to consume whole $A$. parvula in this study were similar to fishes reported (most notably, wrasses) to eat the sea hare Stylocheilus longicauda (Paul \& Pennings 1991) and other opisthobranchs (Gochfeld \& Aeby 1997, Avila \& Paul 1997). The susceptibility of A. parvula to predators was slightly higher at Gun Beach than at Western Shoals. Generally, there were more parrotfish and damsels (Scarus spp. and Amblyglyphidodon spp., respectively), and fewer wrasses (Thalassoma spp.) present at Western Shoals compared with Gun Beach.
This may be because Western Shoals is a popular tourist site where recreational divers feed fish several times a day. It is possible that diet-derived secondary metabolites in opisthobranchs may deter some fish predators but are ineffective against others, such as tolerant (e.g., wrasses) or opportunistic (e.g., damselfish) predators (Pennings \& Paul 1993, Avila \& Paul 1997). While fishes are not the only predators on opisthobranch molluscs, they will readily consume nudibranchs (Avila \& Paul 1997, Gochfeld \& Aeby 1997) and ascoglossans (Trowbridge 1994) when conspicuous and available to them. Crabs (Trowbridge 1994) and other invertebrate predators (Carefoot 1987, Pennings 1990a,b, Johnson \& Willows 1999) also have been shown to consume opisthobranchs and may act as important predators in limiting natural assemblages of these animals.

In field assays, reef fishes consumed frozen Aplysia parvula, however, no live animals were eaten. Aplysia parvula releases ink when physically disturbed, similar to that reported for other sea hares (Carefoot 1987, Johnson \& Willows 1999). While Dimatteo $(1981,1982)$ has suggested that the inking behavior of sea hares acts as a means of defense against predators, sea hare ink is not known to contain any algal secondary metabolites nor is its natural function(s) well known (Carefoot 1987, Pennings 1994, Johnson \& Willows 1999). Carefoot et al. (1999) showed ink to act as a sensory irritant to a number of types of invertebrates and fishes. Whether the ink of live A. parvula was a basis for its unpalatability to reef fishes is not clear, but is a possible factor in affecting the vulnerability of these animals to predation on Guam.

Sea hares found on Portieria hornemannii were unpalatable to reef fishes, but animals found on Acanthophora spicifera were readily eaten. These results are consistent with chemical data (Fig. 10b) which showed that $A$. parvula sequester apakaochtodenes from a $P$. hornemannii diet. Concentrations of apakaochtodenes in animals were nearly an order of magnitude higher than those found in the alga. Sea hares found living on A. spicifera, which is not known to contain any unpalatable secondary metabolites, had no apakaochtodene compounds or any other detectable chemical defenses. Similarly, Pennings (1990a) showed that when the sea hare Aplysia californica was grown on a algal diet rich in secondary metabolites animals were less palatable to fish than when they had been grown on an algal diet lacking secondary metabolites altogether.

The body parts (digestive gland and mantle) of Aplysia parvula were also unpalatable to reef fishes. However, while reef fishes clearly showed no preference for individual body parts from Double Reef, fishes tended to more often consume mantle compared with 
digestive gland parts from Apaca Point. Concentrations of apakaochtodenes in A. parvula varied between different body parts with algal compounds significantly present in the digestive gland compared to mantle. These data are consistent with previous findings of quantitative (Pennings \& Paul 1993, de Nys et al. 1996) and qualitative variation (Winkler 1969, Gerwick \& Whatley 1989, Faulkner 1992) of algal secondary metabolites in sea hares. Since sea hares sequester algal metabolites in their digestive gland (where they are not optimally located for defense) rather than mantle tissues, the anti-predatory role of these compounds has been disputed (Pennings \& Paul 1993, Pennings 1994, de Nys et al. 1996). However, several studies have demonstrated that sea hare mantle is unpalatable to predators (Ambrose et al. 1979, Pennings 1990a, 1994, Pennings et al. 1999). It is possible that sea hares may produce an unpalatable compound which is of greater defensive value than dietderived metabolites (Pennings \& Paul 1993, Pennings 1994, Pennings et al. 1999). While this latter argument cannot be ignored, our data indicate that $A$. parvula body parts are unpalatable to most reef fish and are consistent with the hypothesis that algal secondary metabolites acquired by sea hares function as predator deterrents (Pennings 1990a, Paul \& Pennings 1991, Faulkner 1992, de Nys et al. 1996).

Acknowledgements. Special thanks to R. Thacker for his suggestions and statistical advice and also to M. Becerro for his helpful comments regarding experimental design during this project. M. Ada, A. Himaya, R. Hormillosa, and Z. Lynn from the Guam Police Department Crime Laboratory provided technical assistance with the gc-ms. J. Biggs, V. Ginsburg, A. Junck, E. Irish, L. Kirkendale, D. Matlock, and J. Starmer assisted with collecting specimens in the field and laboratory assays. Special thanks to committee members C. Birkeland, P. Motavalli and L. Yudin for their support and advice to DWG. S. Murray and three anonymous reviewers greatly improved this manuscript. This work was completed as partial fulfillment of the M.S. degree by DWG and is contribution \#440 of the University of Guam Marine Laboratory. This research was funded by NSF grant HRD 9023311.

\section{LITERATURE CITED}

Ambrose HW III, Givens RP, Chen R, Ambrose KP (1979) Distastefulness as a defense mechanism in Aplysia brasiliana (Mollusca: Gastropoda). Mar Behav Physiol 6:57-64

Avila C, Paul VJ (1997) Chemical ecology of the nudibranch Glossodoris pallida: is the location of diet-derived metabolites important for defense? Mar Ecol Prog Ser 150: 171-180

Becerro M, Starmer JA, VJ Paul (1998) Intracolonial variation in chemical defenses of the sponge Cacospongia sp. and its consequences on generalist fish predators and the specialist nudibranch predator Glossodoris pallida. Mar Ecol Prog Ser 168:187-196

Brawley SH (1992) Mesoherbivores. In: John DM, Hawkins
SJ, Price JH (eds) Plant-animal interactions in the marine benthos. Clarendon Press, Oxford, p 235-263

Carefoot TH (1987) Aplysia: its biology and ecology. Oceanogr Mar Biol Annu Rev 25:167-284

Carefoot TH, Pennings SC, Danko JP (1999) A test of the novel function(s) for the ink of sea hares. J Exp Mar Biol Ecol 234:185-197

Carlton DJ, Lubchenco J, Sparrow MS, Trowbridge CD (1989) Fine-scale variability of lanosol and its disulfate ester in the temperate red alga Neorhodomela larix. J Chem Ecol 15:1321-1333

Cronin G, Hay ME (1996a) Within-plant variation in seaweed palatability and chemical defenses: optimal defense theory versus the growth-differentiation balance hypothesis. Oecologia 105:361-368

Cronin G, Hay ME (1996b) Induction of seaweed chemical defenses by amphipod grazing. Ecology 77(8):2287-2301

de Nys R, Steinberg PD, Rogers CN, Charlton TS, Duncan MW (1996) Quantitative variation of secondary metabolites in the sea hare Aplysia parvula and its host plant, Delisea pulchra. Mar Ecol Prog Ser 130:135-146

de Nys R, Dworjanyn SA, Steinberg PD (1998) A new method for determining surface concentrations of marine natural products on seaweeds. Mar Ecol Prog Ser 162:79-87

Di Marzo V, Marin A, Vardaro RR, De Petrocellis L, Villani G, Cimino G (1993) Histological and biochemical bases of defense mechanisms in four species of Polybranchioidea ascoglossan molluscs. Mar Biol 117:367-380

Dimatteo T (1981) The inking behavior of Aplysia dactylomela (Gastropoda: Opisthobranchia): evidence for distastefulness. Mar Behav Physiol 7:285-290

Dimatteo T (1982) The ink of Aplysia dactylomela (Rang 1828) (Gastropoda: Opisthobranchia) and its role as a defense mechanism. J Exp Mar Biol Ecol 57:159-180

Duffy JE, Hay ME (1991) Food and shelter as determinants of food choice by an herbivorous marine amphipod. Ecology 72:1286-1298

Duffy JE, Hay ME (1994) Herbivore resistance to seaweed chemical defense: the roles of mobility and predation risk. Ecology 75:1304-1319

Faulkner DJ (1992) Chemical defenses of marine molluscs. In: Paul VJ (ed) Ecological roles of marine natural products. Comstock Press, Ithaca, p 119-163

Fuller RW, Cardellina JH II, Kato Y, Brinen LS, Clardy J, Snader KM, Boyd MR (1992) A pentahalogenated monoterpene from the red alga Portieria hornemannii produces a novel cytotoxicity profile against a diverse panel of human tumor cell lines. J Med Chem 35:3007-3011

Fuller RW, Cardellina JH, II, Jurek J, Scheur PJ, AlvaradoLinder B, McGuire M, Gray GN, Steiner JR, Clardy J, Menez E, Shoemaker RH, Newman DJ, Snader KM, Boyd MR (1994) Isolation and structure/activity features of halomon-related antitumor monoterpenes from the red alga Portieria hornemannii. J Med Chem 37:4407-4411

Futuyma DJ, Moreno G (1988) The evolution of ecological specialization. Annu Rev Ecol Syst 19:207-233

Gerwick WH, Whatley G (1989) Aplysia sea hare assimilation of secondary metabolites from brown seaweed, Stypopodium zonale. J Chem Ecol 15(2):677-683

Gochfeld DJ, Aeby GS (1997) Control of populations of the coral-feeding nudibranch Phestilla sibogae by fish and crustacean predators. Mar Biol 130:63-69

Gunatilaka L, Paul VJ, Park PU, Puglisi MP, Gitler A, Eggleston DS, Haltiwanger RC, Kingston DGI (1999) Apakaochtodenes A and B: two tetrahalogenated monoterpenes from the red marine alga Portieria hornemannii. J Nat Prod 62(10):1376-1378 
Hay ME (1992) The role of seaweed chemical defenses in the evolution of feeding specialization and in the mediation of complex interactions. In: Paul VJ (ed) Ecological roles of marine natural products. Comstock Press, Ithaca, p 93-118

Hay ME (1996) Marine chemical ecology: what's known and what's next? J Exp Mar Biol Ecol 200:103-134

Hay ME, Fenical W (1988) Marine plant-herbivore interactions: the ecology of chemical defense. A Rev Ecol Syst 19:111-145

Hay ME, Steinberg P D (1992) The chemical ecology of plantherbivore interactions in marine versus terrestrial communities. In: Rosenthal GA, Berenbaum MR (eds) Herbivores: their interactions with secondary plant metabolites; Vol. II: Evolutionary and ecological processes. Academic Press, San Diego, p 371-413

Hay ME, Duffy JE, Pfister CA, Fenical W (1987) Chemical defense against different marine herbivores: Are amphipods insect equivalents? Ecology 68:1567-1580

Hay ME, Pawlik JR, Duffy JE, Fenical W (1989) Seaweedherbivore-predator interactions: host-plant specialization reduces predation on small herbivores. Oecologia 81: $418-427$

Hay ME, Duffy JE, Fenical W (1990a) Host-plant specialization decreases predation on a marine amphipod: an herbivore in plants clothing. Ecology 71:733-743

Hay ME, Duffy JE, Paul VJ, Renaud PE, Fenical W (1990b) Specialist herbivores reduce their susceptibility to predation by feeding on the chemically defended seaweed Avrainvillea longicaullis Limnol Oceanogr 35:1734-1743

Hay ME, Stachowicz J J, Cruz-Rivera E, Bullard S, Deal MS, Lindquist $N$ (1998) Bioassays with marine and freshwater macroorganisms. In: Haynes KF, Millar JG (eds) Methods in chemical ecology. Chapman and Hall (Kluwer Academic Press), Boston, p 39-41

HP ChemStation (1993) HP-G1034C for ChemStation (DOSseries). Hewlett-Packard Company, Palo Alto, CA

Jeffries MJ, Lawton JH (1984) Enemy free space and the structure of ecological communities. Biol J Linn Soc 23:269-286

Johnson PM, Willows AOD (1999) Defense in sea hares (Gastropoda, Opisthobranchia, Anaspidea): multiple layers of protection from egg to adult. Mar Fresh Behav Physiol 32: $147-180$

Lachat Instruments (1992) Total Kjeldahl nitrogen in soil/ plant. QuikChem method13-107-06-2D. Lachat Instruments, Milwaukee, WI

Matlock DB, Ginsburg DW, Paul VJ (1999) Spatial variability in secondary metabolite production by the tropical red alga Portieria hornemannii. Hydrobiologia 398/399: 263-273

Meyer KD, Paul VJ (1992) Intraplant variation in secondary metabolite concentration in three species of Caulerpa (Chlorophyta: Caulerpales) and its effects on herbivorous fishes. Mar Ecol Prog Ser 82:249-257

Meyer KD, Paul VJ, Sanger HR, Nelson SG (1994) Effects of seaweed extracts and secondary metabolites on feeding by the herbivorous surgeonfish Naso lituratus. Coral Reefs 13:105-112

Meyer KD, Paul VJ (1995) Variation in secondary metabolite and aragonite concentrations in the tropical green seaweed Neomeris annulata: effects on herbivory by fishes. Mar Biol 122:537-545

Nagle DG, Camacho FT, Paul VJ (1998) Dietary preferences of the opisthobranch mollusc Stylocheilus longicauda for secondary metabolites produced by the tropical cyanobacterium Lyngbya majuscula. Mar Biol 132:267-273

Nelson DW, Sommers LE (1975) A rapid and accurate proce- dure for estimation of organic carbon in soil. Proc Indiana Acad Sci 84:456-462

Paul VJ (1992) Seaweed chemical defenses on coral reefs. In: Paul VJ (ed) Ecological roles of marine natural products. Comstock Press, Ithaca, p 24-42

Paul VJ, Pennings SC (1991) Diet-derived chemical defenses in the sea hare Stylocheilus longicauda (Quoy et Gaimard 1824). J Exp Mar Biol Ecol 151:227-243

Paul VJ, Hay ME, Duffy JE, Fenical W, Gustafson K (1987) Chemical defense in the seaweed Ochtodes secundiramea (Montagne) Howe (Rhodophyta): Effects of its monoterpenoid components upon diverse coral-reef herbivores. J Exp Mar Biol Ecol 114:249-260

Paul VJ, Nelson SG, Sanger HR (1990) Feeding preferences of adult and juvenile rabbitfish Siganus argentus in relation to chemical defenses in tropical seaweeds. Mar Ecol Prog Ser 60:23-24

Paul VJ, Meyer KD, Nelson SG, Sanger HR (1992) Deterrent effects of seaweed extracts and secondary metabolites on feeding by the rabbitfish Siganus spinus. Proc 7th Int Coral Reef Symp 2:867-874

Pennings SC (1990a) Predator-prey interactions in opisthobranch gastropods: effects of prey body size and habitat complexity. Mar Ecol Prog Ser 62:95-101

Pennings SC (1990b) Multiple factors promoting narrow host range in the sea hare, Aplysia californica. Oecologia 82: $192-200$

Pennings SC (1994) Interspecific variation in chemical defenses in the sea hares (Opisthobranchia: Anaspidea). J Exp Mar Biol Ecol 180:203-219

Pennings SC, Paul VJ (1993) Sequestration of dietary secondary metabolites by three species of sea hares: location, specificity and dynamics. Mar Biol 117:535-546

Pennings SC, Paul VJ, Dunbar DC, Hamann MT, Lumbang WA, Novack B, Jacobs RS (1999) Unpalatable compounds in the marine gastropod Dolabella auricularia: distribution and effect of diet. J Chem Ecol 25:735-755

Peterson CH, Renaud PE (1989) Analysis of feeding preference experiments. Oecologia 80:82-86

Poore A (1994) Selective herbivory by amphipods inhabiting the brown alga Zonaria angustata. Mar Ecol Prog Ser 107: 113-123

Price WP, Bouton CE, Gross P, McPheron BA, Thompson JN, Weiss AE (1980) Interactions among three trophic levels. Influence of plants on interactions between herbivores. Annu Rev Ecol Syst 11:41-65

Puglisi MP, Paul VJ (1997) Intraspecific variation in the red alga Portieria hornemannii: monoterpene concentrations are not influenced by nitrogen or phosphorus enrichment. Mar Biol 128:161-170

Rogers CN, Steinberg PD, de Nys R (1995) Factors associated with oligophagy in two species of sea hares (Mollusca: Anaspidea). J Exp Mar Biol Ecol 192:47-73

Schmitt TM, Hay ME, Lindquist N (1995) Constraints on chemically mediated coevolution: multiple functions for seaweed secondary metabolites. Ecology 76:107-123

Steinberg PD (1995) Interaction between the canopy dwelling echinoid Holopneustes purpurescens and its host kelp Ecklonia radiata. Mar Ecol Prog Ser 127:169-181

Switzer-Dunlap M (1978) Larval biology and metamorphosis of Aplysiid gastropods. In: Chia FS, Rice ME (eds) Settlement and metamorphosis of marine invertebrate larvae. Elsevier, New York, p 197-206

Switzer-Dunlap M, Hadfield MG (1977) Observations on development, larval growth and metamorphosis of four species of Aplysiidae (Gastropod: Opisthobranchia) in laboratory culture. J Exp Mar Biol Ecol 29:245-261 
Trono GC Jr (1969) The marine benthic algae of the Caroline Islands. II. Phaeophyta and Rhodophyta. Micronesica 5: 25-119

Trono GC Jr (1997) Field guide and atlas of the seaweed resources of the Philippines. Bookmark, Inc., Makati City, Philippines, p 201-203

Trowbridge CD (1992) Mesoherbivory: The ascoglossan sea slug Placida dendritica may contribute to the restricted distribution of its algal host. Mar Ecol Prog Ser 83: 207-220

Trowbridge CD (1994) Defensive responses and palatability

Editorial responsibility: Charles Birkeland (Contributing Editor), Honolulu, Hawaii, USA of specialist herbivores: predation on NE Pacific ascoglossan gastropods. Mar Ecol Prog Ser 105:61-70

Van Alstyne KL (1989) Adventitious branching as an herbivore induced defense in the intertidal brown alga Fucus distichus. Mar Ecol Prog Ser 56:169-176

Wakefield RL, Murray SN (1998) Factors influencing food choice by the seaweed-eating marine snail Norrisia norrisi (Trochidae). Mar Biol 130:631-642

Winkler LR (1969) Distribution of organic bromine compounds in Aplysia californica Cooper, 1863. Veliger 11: 268-271

Submitted: August 15, 2000; Accepted: August 25, 2000 Proofs received from author(s): April 23, 2001 